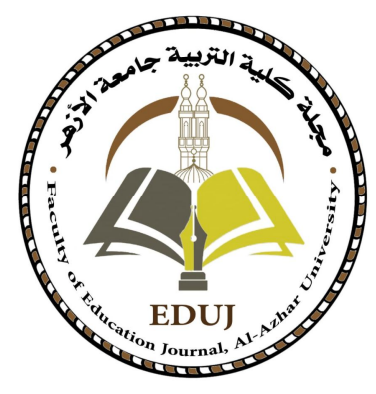

\title{
The Challenge of Being a Higher Education
} Student with Learning Disability: Examining Available and Needed Support

$$
\text { التحدي في أن تكون طالباً في التعليم العالي هن ذوي صعوبات التعلم: التحقي }
$$

\section{By}

\author{
Dr. Randa Ahmad Hariri
}

Master Program of Educational Leadership

Hekma School of Health, Behavioral Sciences and Education

Dar Al Hekma University, KSA 
The Challenge of Being a Higher Education Student . with Learning Disability: Examining Available and Needed Support

Randa Ahmad Hariri

Master Program of Educational Leadership, Hekma School of Health, Behavioral Sciences and Education, Dar Al Hekma University, KSA

E-mail: dr.randa.hariri.abousamra@gmail.com

\begin{abstract}
:
The number of students with Learning Disabilities (LD) is increasing in the Kingdom of Saudi Arabia (KSA). The context of this study constitutes around $5 \%$ of the student with disabilities population. This research aims to, a) discover the various types of support that higher education institutions (HEIs) in KSA provide to their students who are diagnosed with $\mathrm{LD}, \mathrm{b}$ ) investigate the nature of challenges that students with LD face, and c) examine the challenges that teachers in HEIs face in providing the support needed for students with LD. This research study involves one public and one private HEI in the city of Jeddah, Saudi Arabia. This research study utilized questionnaires administered to 24 students with LD and 168 teachers in these institutions. Results revealed that these students are not provided with the needed academic support, and most of them do not even receive feedback on their work along with how to improve it. Results also revealed that most teachers are not provided with professional development programs for accommodating students with LD, and also not having proper communication with teachers to describe available cases along with ways to deal with them.
\end{abstract}

Keywords: Learning Disability, Higher Education, Examining Available and Needed support. 


$$
\text { كلية التربية بالثقاهرة العدد: (187)، الجزبة الجزية (الثالث)، يوليو لسنة 2020م }
$$

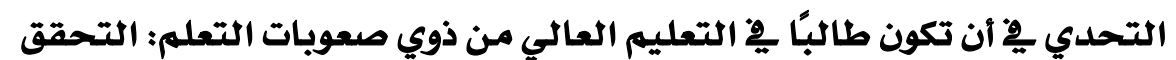

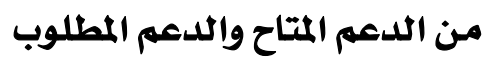

$$
\text { رندة أحمد حريري }
$$

برنامج الماجيستير ِِ القيادة التربوية، كلية العلوم الصحية والسلوكية والنعليه، جامعة دار

$$
\text { الحكمة، المملكة العربية السعودية. }
$$

البريد الإلكتروني: dr.randa.hariri.abousamra@gmail.com

الملنخص:

تهدف هذه الدراسة إلى اكتشاف أنواع الدعم المختلفـة التي تقـدمها مؤسسسات التعليهم العـالي مِّ المملكة العربية السعودية لطلابها الذين تم تشخيص إصـابتهم بصعوبة التعلهم، والتحقق مـن طبيعـة التحسديات الـتي يواجهها هؤلاء الطلبـة ، بالإضـافة إلى إكتشاف التحسديات التتي

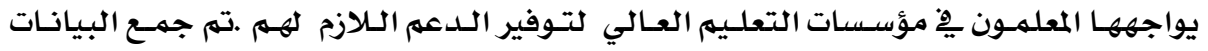
باستخدام الإستبانة كأداة للبـحث والتي وزعت على (168 ) معلمى ومعلمـة يِ جامعـة حكوميـة وجامعة خاصة يِّ مدينة جدة و (25) طالب وطالبـة مـن ذوي صعوبات التعلهم. وبعـد ذلك تم تحليل البيانات باستخدام برنامج رزمة التحليل الإحصائي (SPSS ) نسخة (24) .وكشفت

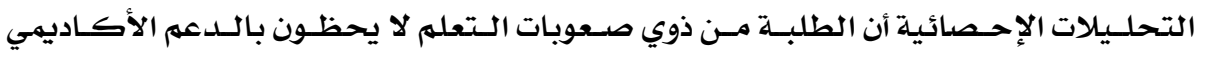
المطلـوب ، وأن معظمهـهم يواجهـون تحسديات بعـدم تلقـي تغذليـة راجعـة حسول عملـهم وكيفيـة

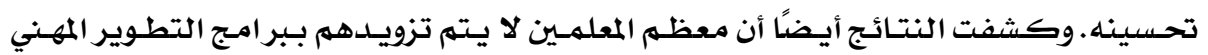
ليسـاعدهم على التعامل مـع الطلبة الذين يعانون من صعوبات التعلهم، هـذا بالإضـافة إلى عدم التواصـل المناسـب مـع غيرهـم مـن المعلمـين لوصف الحـالات المتاحـة وطـرق التعامـل معهـا كمـا يلزم· الكلمات المفتاحية: التحدي، صعوبات التعلهم، التعليم العالي، الدعم المتاح، الدعم المطلوب. 


\section{Introduction}

LD is the main heading for many disorders that include Dyslexia, Dyscalculia, Dysgraphia, Auditory Processing Disorder (APD), Non-Verbal LD, and Visual Perceptual/Visual Motor Deficit. Attention Deficit Hyperactivity Disorder (ADHD), Dyspraxia and difficulty in reading, are disorders that are associated with LD due to their unfavorable effect on learning and achievement (Bishnoi, 2017). In fact, "Learning Disability" is a term that encompasses a group of brain dysfunction disorders (Vargo, 2015), which adversely affects the ability of students to learn and hinders their achievement throughout their primary, secondary and postsecondary education. Nevertheless, providing the appropriate strategies and needed support to these students proved to be instrumental in enriching their learning experience and maximizing their achievement (Collinson \& Penketh, 2010; Gerber et al., 1990; Ingesson, 2007).

Although early intervention is recommended to help students with LD develop their own strategies to learn better, these students still need additional or a special kind of support throughout their learning journey, especially during and after their transition from secondary to postsecondary education (Crawford,2012).

\section{Study Problem}

The number of students with LD, including but not limited to, Dyslexia, Dyscalculia, Dysgraphia and other related types such as Attention Deficit and Hyperactivity Disorder (ADHD), is increasing in KSA, which is the context of this study. The last estimate of the number of students having specific LD indicates 250,000 which comprises $5 \%$ of the Saudi students with disabilities population (Bin Battal, 2016). More specifically, Bin Battal (2016) indicates that the number of students with $L D$ who are enrolled in special institutes or centers for $L D$ are 26225 students. These students are among the expected enrollees in HEIs in the Kingdom, where they still need various types of support at all levels including the academic, psychological, emotional and social levels. 

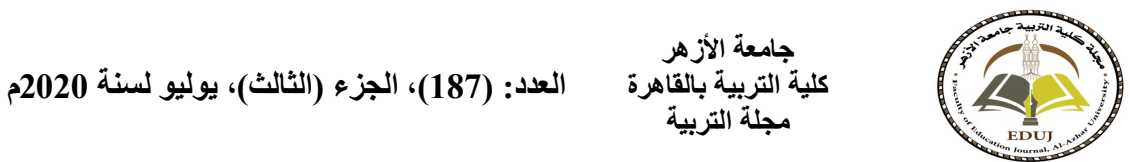

Study Questions:

The problem of this study is manifested in the following research questions:

1. What kind of support do HEIs in KSA provide to students with LD?

2. What are the challenges that students face in their learning in HEIs in KSA?

3. What are the challenges that teachers in HEIs in KSA face that hinder or limit provision of support to students with LD?

\section{Study Purpose:}

The purpose of the study is to examine the kind of support that higher education institutions provide to students with learning disabilities, that would help them pursue their learning in their postgraduate studies, as well as to examine the various types of challenges that students with learning disabilities face in their learning journey in higher education. Furthermore, this study aims to discover the challenges that faculty members in these institutions face and preventing them from providing the needed support to students with learning disabilities.

\section{Study Limits:}

This study was defined in terms of the samples who were undergraduate and graduate students diagnosed with learning disability, as well as teachers at one public and one private higher education institution in the city of Jeddah, KSA. In addition, it was conducted during the academic year of 2019/2020. Finally, its focus was on examining the challenges that these students face during their learning journey, in addition to the challenges that teachers face in educating these students.

\section{Literature Review:}

Students with LD at HEIs, generally exhibit lower academic achievement than their peers which does not relate to a reduced or lack of vision, speech, hearing, or intelligence (Fletcher, Lyon, Fuchs, \& Barnes, 2007; American Psychiatric Association, 2013a, 2013b), but rather to differences in cognitive abilities (Lewis, 2011). The low academic achievement associated with negative school reports have contributed to lowering students' self-esteem (Fletcher et al., 2007; Gibson \& Kendall, 
2010; Lahane et al., 2013). Moreover, these students have strengths and weaknesses as well as challenges that make their learning profiles quite complex. This sheds light at the readiness of the existing academic system in the HEIs in KSA to meet the various needs of such a diverse and demanding group of students (Binbattal, 2016).

This research study relates to the existing literature in regard to the available types of support that are provided to and needed by the students with $L D$ in higher education. The challenge of having students with $L D$ in a normal class setting is a pressing issue for educators and specialists in the field. Whilst many research studies have been conducted worldwide, very few research studies have been conducted in KSA (Bin Battal, 2016).

Learning at HEIs is naturally very demanding for any student, and it is even more demanding for students with $L D$. Many research studies have been conducted to explore the challenges that students with $L D$ face during their educational journey at HEIs. Such challenges include, struggling in managing their time, receiving constructive feedback to improve their work, and diversifying the teaching strategies to meet their needs (Fuller et al., 2004; Goode, 2006; Collinson \& Penketh, 2010; Gibson \& Kendall, 2010; Hutcheon \&Wolbring, 2012). These studies came up with an array of strategies that can be utilized with students with $L D$, together with the appropriate kind of services, this can be provided to support them. Unfortunately, and based on a comprehensive review of literature, no similar studies have been conducted in KSA to reveal the challenges faced by students in HEIs as well as the support they receive, and need to receive, to pursue their studies and maximize their achievements.

In the same vein, Heiman and Precel (2003) declare that the number of students with LD enrolling in HEIs is increasing. More specifically, students with reading difficulties continue to experience academic challenges as they reach adulthood and embark on postsecondary education (e.g., Collinson \& Penketh, 2010; Gerber et al., 1990; Ingesson, 2007). Furthermore, a study conducted by Hadley \& Satterfield (2013) indicates that students with $L D$ continue to struggle in developing their intellectual skills and practical emotional discipline until they become independent learners within higher education contexts. This demonstrated struggle justifies the need for special services that the HEIs must provide to students with $L D$ to enhance their learning and maximize their achievements. This support can be provided to students with any type of $L D$ from myriads of resources and at 


$$
\text { كلية التربية بالقاهرة العدد: (187)، الجزءء (الثالث)، يوليو لسنة 2020م }
$$

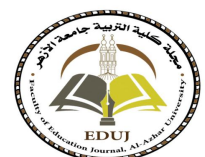

different levels including policy makers, HEIs' upper management, middle management, administrators, and teachers.

At the policy maker or governmental level, Mortimorea and Crozierbin (2006) emphasize the importance of developing suitable policies and practices that inform HEIs that mandate designing and providing effective support to students with $L D$, to enhance their learning after their transition from secondary to postsecondary education.

As far as the context of this study is concerned, Alkhashrami (2011) conducted a research study on 85 students diagnosed with special needs in King Saud University, who indicated that they continue to face challenges due to their disabilities and the very limited services provided to them at the University.

In the same regard, Alquraini (2011) indicated that the government of KSA recognizes the needs of students with mild, moderate, multiple, and severe disabilities and bestowed them with special attention in terms of providing necessary funds, special facilities, along with services. Nevertheless, there is no demonstrated or evidence-based translation of this intended attention towards students with LD in HEIs. In this vein, Aldabas (2015) states that although the policy makers in the Ministry of Education in the Kingdom are showing increasing attention to students with LD in primary and secondary schools, they are not giving equal attention to those in HEIs. This attention ranges from exempting them from all due fees, to providing the teachers with special training programs, all the way to better prepare them to teach and deal with students with special learning needs.

From another angle, and in regard to deciding on the kind of support that HEIs should provide to students, there must be rigorous assessment of the needs of students with $L D$, in order to provide them with the necessary tools and facilities to ensure students' success. Although most students with Dyslexia develop their own learning strategies and study skills during their secondary education and transfer them to postsecondary education, yet they would still need additional support to help them cope with all the ensuing changes and challenges of studying at HEIs (Fuller et al., 2004). Accordingly, it is significant to discover various kinds of support that students with Dyslexia or with any other type of Learning Disability need since HEIs host all types of LD (Mortimorea and CrozierbIn, 2006). At this point, it is 
pertinent to consider the kinds of support or services that students with LD need to enhance their learning along with improving their achievement (Herring, 2012).

Accordingly, policy makers in KSA are tirelessly working towards having exemplary educational institutions, hence, placing high emphasis on enhancing the learning opportunities of students with special needs including those with $L D$ in its 2030 Vision. In this regard, Alothman (2014) claims that the Saudi policies instruct that schools and HEIs should provide individuals with disabilities the education and the needed support to have proper learning experience. Based on the law of disability in Saudi Arabia (The Law of Disability in Saudi Arabia, 2000), it is emphasized that the disabled be served in different domains which includes the educational field. It is significant to note that the law, includes individuals with learning difficulties, since it defines disability to include; physical and motor impairment, speech and language disorders, hearing disabilities, learning difficulties, behavioral and emotional disturbances, mental handicap, and autism, among others (Alharbi \& Madhesh, 2018, p.950).

A brief overview of the history of Saudi Arabia gives a bright idea about the strides that the kingdom has taken in the field of education. The Education system in Saudi Arabia has undergone dramatic changes since its establishment in 1932. This change took place at the primary, secondary and tertiary levels. As it started, education in Saudi Arabia was restricted to males until 1960 when the first school for girls was founded in Riyadh, the capital of Saudi Arabia (Al-Rawaf \& Simmons, 1991), and thus education became open for both genders. In 1957, the government recognized a need to establish the first university, the King Saud University. It was established to educate students in the Kingdom instead of students travelling abroad to find education. This was followed by the establishment of The Ministry of Higher Education as a centralized authority, to administer and monitor the increasing number of colleges and universities in Saudi Arabia (Alamri, 2011). More importantly, in 1958, the Saudi government introduced special education services for students with LD (Aldabas, 2015; Al-Mousa, et.al, 2006). Nevertheless, these services were focused in 2393 special centers which provide special services to an estimate of 26,225 students with LD (Bin Battal, 2016).

The services accommodating students with LD must expand to cater to the ever increasing number of students with $L D$ enrolled in HEIs in the Kingdom. As the support for such students is limited, as well as there being fewer programs available for them 


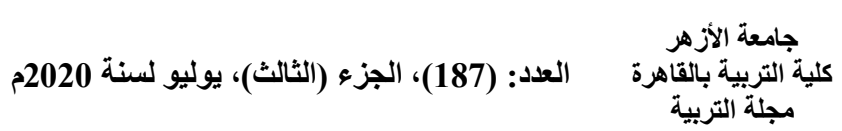

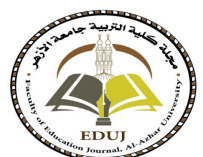

when they are in HEIs, operations are not monitored to include students with disabilities. There is a great need to monitor the implementation of policies that govern the handling of all types of LD that students might have, as dictated by the Saudi Law 2000.

\section{Methodology:}

This research study adopted a quantitative descriptive design, which is efficient in achieving the purpose of this study in examining the existing types of support that HEIs offers to students with $L D$, investigating the obstacles and challenges that HEIs face that are hindering the provision of any kind of support for these students.

\section{Sampling:}

Participants in this study were students with LD and teachers in a public and a private university in the city of Jeddah, KSA. This sample was selected based on a simple random sampling procedure among teachers who teach in both public and private universities, as well as students who have been previously diagnosed and hold a clinical report that certifies their disability in a simple random process. Accordingly, a questionnaire was sent to all teachers, the "Teachers' Questionnaire", and a different one was sent to all students, the "Students' Questionnaire", in both universities, whereby all were invited to respond willingly and freely. Nevertheless, only students who were diagnosed with LD were invited to participate and respond to the questionnaire. Therefore, and to ensure that this sample includes only students with LD, the questionnaire, which constitutes the research instrument of this study, was sent to all students with an additional question at the beginning, asking whether the student had a learning disability or not, and only students with LD were asked to respond. It is worth mentioning here, that the number of students who are diagnosed with learning disability are not well defined by the administration in both universities, due to difficulties in the diagnosis processes, and the sensitivity of the topic.

We received responses from 168 teachers and 25 students with LD. As these students identified themselves as "students with LD", we assumed that they had undergone psychological evaluation and diagnosis to be able to identify the type of learning disability they have. 
The demographic characteristics of the participants.

Table 1

Frequency distribution of the students' sample according to demographic characteristics

\begin{tabular}{cccc}
\hline Variable & Categories & Frequency & Percent \\
\hline Type of & Private & 1 & $4.0 \%$ \\
University & Public & 24 & $\mathbf{9 6 . 0} \%$ \\
Program of & Bachelor & 9 & $\mathbf{3 6 . 0} \%$ \\
Study & Master & 16 & $\mathbf{6 4 . 0 \%}$ \\
& Learning Disability & $\mathbf{8}$ & $\mathbf{3 2 . 0} \%$ \\
Type of & Dyslexia & 1 & $\mathbf{4 . 0 \%}$ \\
Learning & Dyscalculia & 2 & $\mathbf{8 . 0 \%}$ \\
Disability & Difficulty in Reading & 7 & $\mathbf{2 8 . 0} \%$ \\
& Visual Perceptual/Visual & 7 & $\mathbf{2 8 . 0} \%$ \\
Year of & Motor Deficit & 2 & $\mathbf{8 . 0 \%}$ \\
Study & Freshman & 7 & $\mathbf{2 8 . 0 \%}$ \\
Total & Senior & 16 & $\mathbf{6 4 . 0 \%}$ \\
& Post graduate studies & 25 & $\mathbf{1 0 0 . 0} \%$ \\
\hline
\end{tabular}

Table No. (1) shows the frequency distribution of the students' sample according to demographic characteristics, and it shows that the students' sample consists of (25) students with learning disabilities.

Regarding the Type of university, it is found that the majority $(96.0 \%)$ of the students are from public universities, while the rest $\mathbf{( 4 . 0 \% )}$ are from private universities.

Regarding the Program of Study, it is found that $(64.0 \%)$ of the students are master program students, while the rest $(36.0 \%)$ are bachelor degree students.

Regarding the Type of Learning Disability, it is found that (32.0 $\%)$ of the students have learning disabilities, $(28.0 \%)$ have (Difficulty in Reading), (28.0\%) have (Visual Perceptual/Visual Motor Deficit), $(8.0 \%)$ have (Dyscalculia), and only $(4.0 \%)$ have (Dyslexia).

Regarding the Year of Study, it is found that $(64.0 \%)$ of the students are in the year of (Post graduate studies), $(\mathbf{2 8 . 0 \%})$ are seniors, and only $(8.0 \%)$ are freshman. 


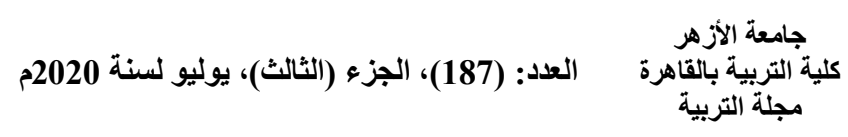

Table 2

Frequency distribution of the teachers' sample according to demographic characteristics

\begin{tabular}{|c|c|c|c|}
\hline Variable & Categories & Frequency & Percent \\
\hline Type of & Private & 31 & $18.5 \%$ \\
\hline \multirow{4}{*}{ University } & Public & 137 & $81.5 \%$ \\
\hline & Computer science & 21 & $12.5 \%$ \\
\hline & Learning Disability & 21 & $12.5 \%$ \\
\hline & English Teachers & 12 & $7.1 \%$ \\
\hline $\begin{array}{l}\text { Specialty or } \\
\text { Discipline }\end{array}$ & $\begin{array}{l}\text { Syllabuses and } \\
\text { Teaching Methods }\end{array}$ & 29 & $17.3 \%$ \\
\hline \multirow[t]{5}{*}{ Teaching In } & Education Techniques & 16 & $9.5 \%$ \\
\hline & Educational & 22 & $13.1 \%$ \\
\hline & Primary Class Teacher & 14 & $8.3 \%$ \\
\hline & Other & 33 & $19.6 \%$ \\
\hline & $0-2$ & 7 & $4.2 \%$ \\
\hline Years of & $3-5$ & 43 & $25.6 \%$ \\
\hline \multirow[t]{2}{*}{ Experience } & $6-10$ & 48 & $28.6 \%$ \\
\hline & More than 10 & 70 & $41.7 \%$ \\
\hline Total & & 168 & $100.0 \%$ \\
\hline
\end{tabular}

Table No. (2) shows frequency distribution of the teachers' sample according to demographic characteristics, and it also shows that the teachers' sample consists of (168) teachers.

Regarding the Type of university, it is found that the majority $(81.5 \%)$ of the teachers are from public universities, while the rest $(18.5 \%)$ are from private universities.

Regarding the specialty or discipline teaching in, it is found that $(\mathbf{1 7 . 3 \%})$ of the teachers specialty is in (Syllabuses and Teaching Methods), (13.1\%) of their specialty is in (Educational), $(12.5 \%)$ of their specialty is in (Computer Science), and (12.5\%) of their specialty is in (Learning disability), $(9.5 \%)$ of the teachers specialty is in (Education Techniques), $(8.3 \%)$ of their specialty is in (Primary Class Teacher), (7.1\%) are (English Teachers), while $\mathbf{( 1 9 . 6 \% )}$ of the teachers have specialties other than those mentioned in the table above.

Regarding years of experience, it is found that $(41.7 \%)$ of the teachers have (more than 10$)$ years of experience, $(28.6 \%)$ have (6 
- 10) years of experience, $(25.6 \%)$ have $(3-5)$ years of experience, and only $(4.2 \%)$ have $(0-2)$ years of experience.

\section{Research Instrument of the Study}

To answer the research questions, two questionnaires, the "Teachers Questionnaire" and the "Students' Questionnaire", were constructed and distributed to the participants in one public and one private higher education institution in the city of Jeddah, Saudi Arabia, to collect data. The "Students' Questionnaire" was sent to all students but it only addressed students with $L D$, while the "Teachers Questionnaire" was distributed to all teachers in both institutions. The questionnaires constitute the quantitative research instrument (QUEST-QUAN), which is based on closedended questions, as these types of questionnaires are more efficient to collect and analyze data from (Teddlie \&Tashakkari, 2009; Creswell, 2012). Themes from previous related literature, were used to construct the dimensions and the items of the questionnaires which aimed to discover the various kinds of support that HEIs provide to students with $L D$, the challenges that the institutions face that might hinder providing any kind of needed support to these students, and the kinds of care the students with LD need to enhance their learning experience. In the questionnaires, student participants were asked to provide demographic information regarding the type of university, whether its public or private, program of study, type of learning disability, and the year of study. They were also asked to answer questions designed to examine quantitative data regarding academic, behavioral, social, physical, and moral support that the university and teachers provide them, in addition to the main challenges that they face that affect their learning.

Teacher participants were asked about the type of universities along with the specialty or discipline they are instructing in, accompanied by their years of experience. They were also asked to complete a questionnaire that was designed to examine quantitative data regarding the challenges they face in supporting students with $\mathbf{L D}$.

The students' questionnaire contains six dimensions that consists of 64 items. 18 items are related to academic support, 12 items are related to the behavioral support, nine items are related to social support, nine items are related to physical support, five items are related to moral support, and 11 items are related to the challenges they face that affect their learning. The teachers' questionnaire consists of seven items that are related to the 

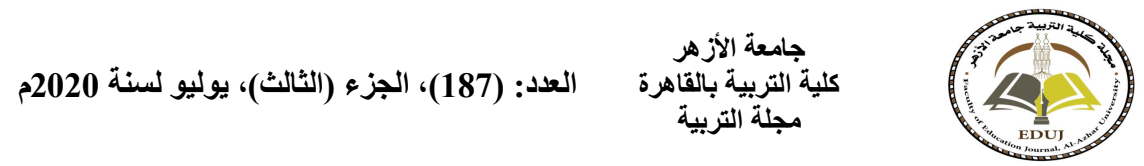

dimension that consists of the challenges they face in providing support to students with LD.

Students with LD constituted the target group of this research study that these institutions serve. Their opinion should be significant to both the teachers and the institutions' stakeholders. Collecting data from students and teachers is noteworthy to ensure obtaining data is gathered from different sources and perspectives.

The response level was measured using the five-scale bipolar scaling method,

$(1=$ Strongly Agree; $2=$ Agree; $3=$ Neutral; 4= Disagree; $5=$ Strongly Disagree; Not applicable) that measures either the positive or the negative response to a statement (Cronbach, 1951).

Table 3

Five-level Likert scale items

\begin{tabular}{ccc}
\hline Answer & Weight & Weighted Mean \\
\hline Strongly Disagree & 1 & 1 to $<1.8$ \\
Disagree & 2 & 1.8 to $<2.60$ \\
Neutral & 3 & 2.60 to $<3.40$ \\
Agree & 4 & 3.40 to $<4.20$ \\
Strongly Agree & 5 & 4.20 to 5
\end{tabular}

In the "Students' Questionnaire", dimensions that addressed the academic support included, accessibility to course materials, modifying teaching methods, giving students more time during exam taking, using simpler language to enhance students' understanding, repeating instructions as needed, presentation of materials, giving constructive and immediate feedback, taking examinations in different place, assigning someone to take notes, using visual aids, etc. The dimension that addressed the behavioral support included, establishing rules to follow up with the students, providing individualized intervention, providing counseling therapy, training on time-management skills, as well as other skills. The dimension that is related to social support included, training on social cues, training on problem-solving skills, providing opportunities to work in teams, promoting students' self-esteem, and more. The dimension that are related to physical support included providing physical therapy, occupational 
therapy, technical aids, and overcoming any physical barriers. The dimension related to moral support included, acknowledging students' rights with dignity and respect, maintaining the integrity of academic standards, and always maintaining students' confidentiality. Finally, the dimension that addressed the challenges that affect their learning include, questions that ask about the presentation of materials, time allowed for exams, time allowed to complete courses, feedback, and the way cognitive training is provided.

In regard to the teachers' questionnaire, the dimension that addressed the challenges that teachers face that will impede their ability to provide support to students with $L D$ included the availability of: funds to get resources, reliable diagnostic reports, awareness about types $L D$, proper communication with teachers, academic support center, counseling services, and finally the availability of professional development programs.

For each item in the questionnaire, students were asked to rate their agreement or disagreement on the availability of the services, or the categories of support they are receiving and to indicate their level of agreement or disagreement on facing the identified challenges in their learning. Same for the teachers' questionnaire, who were asked to rate their level of agreement or disagreement on facing the identified challenges in providing support to students with $\mathrm{LD}$.

\section{Questionnaire Validity and Reliability Internal Consistency (Validity)}

To ensure the accuracy of the questionnaire in measuring what it is intended to measure, internal consistency (Hair et al., 2006), Pearson Correlation Coefficient was used to test the correlation between each item and the total score of the dimension it belongs to. The results revealed that for each dimension in the students' questionnaire along with the teachers' questionnaire, the correlation coefficients are positive, high, and statistically significant at levels $(0.01)$ and $(0.05)$.

\section{Questionnaires Reliability.}

To ensure reliability of the questionnaires and that the research focuses mainly on stability on getting similar results (Robson 2007; Polit \& Beck 2010), the researcher calculated Cronbach's alpha reliability coefficient which was all calculated to be $>0.7$, thus demonstrating good reliability (Jones \& Rattray, 2010) as shown in the table below. 
Table 4

Reliability test by Cronbach's Alpha method

\begin{tabular}{ccc}
\hline Dimensions & No. of Items & Cronbach's Alpha \\
\hline I. The academic support & 19 & 0.981 \\
II. The Behavioral & 12 & 0.954 \\
support & 9 & 0.972 \\
III. The Social support & 8 & 0.911 \\
IV. The physical support & 5 & 0.947 \\
V. The moral support & 11 & 0.909 \\
VI. The main challenges & 7 & 0.864 \\
Teachers questionnaire & 7 & \\
\hline
\end{tabular}

Data Analysis

Quantitative data were analyzed using the software, Statistical Package for Social Science (SPSS) version (24). The processes and tests employed included, descriptive analysis such as frequencies and percentages, Chronobach's Alpha coefficients, Pearson Correlation Coefficients, mean and standard deviation, and the p-value which is considered significant at $<0.05$.

\section{Results:}

Q 1. What kind of support do HEIs in KSA provide to students with learning disabilities?

To answer the first research question, descriptive statistics was used including mean and standard deviation for the answers of the statements of $(I-V)$ dimensions of students' questionnaire.

\section{Students' Perspectives:}

\section{Support provided:}

As shown in Table No. (5), most responses demonstrated neutral degrees of agreement regarding the students towards the availability of different kinds of support delivered to them by their universities to enhance their learning and maximize their achievements at the academic, behavioral, social, physical or 
moral levels. Nevertheless, responses demonstrated that students with LD receive more moral support than social support, followed by behavioral support, then physical support, and ending with academic support which was the least provided.

Table 5

Means and standard deviations of the kind of support that HEIs in $K S A$ provide to

students with LD

\begin{tabular}{lcccc}
\hline \multicolumn{1}{c}{ Dimension } & Mean & SD & Response level & Order \\
\hline I. The academic support & 2.59 & 1.36 & Disagree & 5 \\
II. The behavioral & 2.84 & 1.03 & Neutral & 3 \\
support & 3.01 & 0.97 & Neutral & 2 \\
III. The social support & 2.64 & 1.00 & Neutral & 4 \\
IV. The physical support & $\mathbf{2 . 1 8}$ & $\mathbf{0 . 9 2}$ & Neutral & 1 \\
V. The moral support & 2.85 & 1.06 & Neutral & \\
\multicolumn{1}{c}{ Total } & & &
\end{tabular}

$\mathrm{SD}=$ Standard Deviation

\section{Areas in Academic Support}

As shown in Table No. (6), responses showed that students are not provided with the necessary academic support. More specifically, students with $L D$ reported that the course materials are neither provided to them in an accessible format, nor are they presented to them in a distinct way. Students' responses also demonstrated that they are not allowed additional time to finish a course or modify a way to present their information. Moreover, responses revealed that students with $L D$ are not provided with feedback on their work or a way to improve it. That's in addition to not being provided with help to take notes or learn with study guides that act as a reference during studying. Finally, responses showed that students with $L D$ are not provided with visual aids or materials and equipment to assist them in learning, in addition to cognitive training for their mental activities that stimulates the brain as well as improve their cognitive skills. 

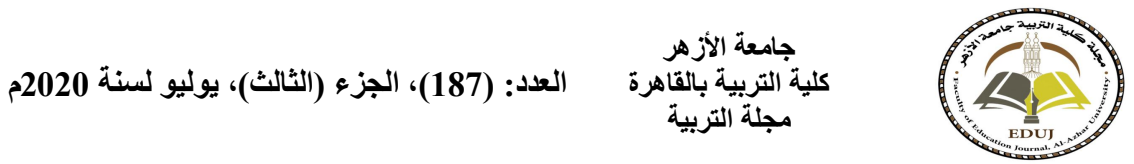

Table 6

Means and standard deviations for the answers of the statements of Dimension I: The academic support

Statements Mean SD $\begin{gathered}\text { Response } \\ \text { level }\end{gathered}$ Order

1. Provide me with course materials in accessible formats.

$\begin{array}{llll}1.92 & 1.19 & \text { Disagree } & 18\end{array}$

2. Utilize flexible/modified teaching methods that fit my learning styles.

3. Give me more time during exam taking.

$\begin{array}{llll}2.64 & 1.22 & \text { Neutral } \quad 9\end{array}$

4. Allow me additional time to complete courses.

$\begin{array}{llll}3.08 & 1.47 & \text { Neutral } & 1\end{array}$

$2.44 \quad 1.08 \quad$ Disagree 12

5. Utilize simpler language with me to enhance my understanding.

$\begin{array}{llll}3.04 & 1.43 & \text { Neutral } & 3\end{array}$

6. Repeat for me the instructions as needed.

$\begin{array}{llll}2.92 & 1.47 & \text { Neutral } & 8\end{array}$

7. Change the way materials is presented to capture my attention and understanding.

$\begin{array}{llll}2.16 & 1.49 & \text { Disagree } & 15\end{array}$

8. Allow me to change the way I present the information.

$\begin{array}{llll}2.56 & 1.39 & \text { Disagree } & 10\end{array}$

9. Demonstrate for me what to do.

$\begin{array}{lll}3.04 & 1.43 & \text { Neutral }\end{array}$

10. Provide me with constructive and immediate feedback on work and on how to improve it.

11. Allow me to take examinations in a different place that best suits me.

$\begin{array}{llll}2.44 & 1.29 & \text { Disagree } & 13\end{array}$

12. Assign someone to take notes

$2.44 \quad 1.33 \quad$ Disagree 14 
Table 6

Means and standard deviations for the answers of the statements of Dimension I: The academic support

Statements Mean SD $\begin{gathered}\text { Response } \\ \text { level }\end{gathered}$ Order

for me.

13. Assign someone to write down my words, for example, in an exam

\subsection{61 Neutral 5}

14. Provide me with visual aids Materials and equipment to help or assist me in learning.

$\begin{array}{llll}1.88 & 1.17 & \text { Disagree } & 19\end{array}$

15. Provide me with reading guides and study guides- Guides that act as a reference for me to look at.

$1.96 \quad 1.43 \quad$ Disagree 17

16. Provide me with direct and explicit Instruction - Explain and provide instructions clearly.

$\begin{array}{llll}2.96 & 1.40 & \text { Neutral } & 7\end{array}$

17. Allow peer Tutoring - allow peer mediated strategy that involves classmates serving as tutors for me.

18. Allow me to record lectures Having the student record lectures will provide valuable revision as well as make sure no $\begin{array}{llll}3.08 & 1.47 & \text { Neutral } & 2\end{array}$ point is left out.

19. Provide me with cognitive training - A program of regular mental activities that stimulates the brain as well as improves cognitive skills.

\section{$\begin{array}{llll}3.00 & 1.41 & \text { Neutral }\end{array}$}

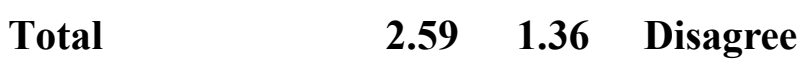

SD = Standard Deviation 

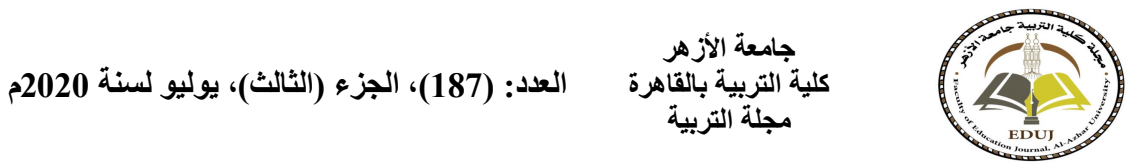

\section{Areas in Behavioral Support}

As shown in Table No. (7), students' responses revealed that they are not provided with behavioral kinds of support regarding training on time-management skills, training on study skills, as well as writing their own behavioral objectives. At the same time, responses demonstrated neutral attitude towards other behavioral kinds of support such as, establishing rules to follow, functional behavioral assessment, individualized intervention, extra break time, counselling therapy, self-management therapy, reinforcement to encourage their learning, removing distractions from the classroom to keep them focused, or applying the best possible classroom modifications.

Table 7

Means and standard deviations of the statements of Dimension II: The behavioral support

\begin{tabular}{|c|c|c|c|c|}
\hline Statements & Mean & SD & $\begin{array}{l}\text { Response } \\
\text { level }\end{array}$ & Order \\
\hline $\begin{array}{l}\text { 1. Establish rules for me to } \\
\text { follow. }\end{array}$ & 3.16 & 1.46 & Neutral & 3 \\
\hline $\begin{array}{l}\text { 2. Provide me with Functional } \\
\text { Behavioral Assessment - Keep } \\
\text { track of my behavior and } \\
\text { understanding to improve it. }\end{array}$ & 2.84 & 1.07 & Neutral & 5 \\
\hline $\begin{array}{l}\text { 3. Provide me with } \\
\text { individualized intervention. }\end{array}$ & 2.76 & 1.01 & Neutral & 9 \\
\hline 4. Give me extra break time. & 3.20 & 0.96 & Neutral & 1 \\
\hline $\begin{array}{l}\text { 5. Provide me counseling } \\
\text { therapy. }\end{array}$ & 2.84 & 0.80 & Neutral & 6 \\
\hline $\begin{array}{l}\text { 6. Provide me self-management } \\
\text { therapy. }\end{array}$ & 2.80 & 0.65 & Neutral & 7 \\
\hline $\begin{array}{l}\text { 7. Provide me training on time- } \\
\text { management skills. }\end{array}$ & 2.36 & 1.25 & Disagree & 12 \\
\hline $\begin{array}{l}\text { 8. Provide me training on study } \\
\text { skills. }\end{array}$ & 2.56 & 1.36 & Disagree & 10 \\
\hline $\begin{array}{l}\text { 9. Coordinate writing my } \\
\text { behavioral objective. }\end{array}$ & 2.48 & 1.26 & Disagree & 11 \\
\hline $\begin{array}{l}\text { 10. Utilize reinforcement to } \\
\text { encourage my learning. }\end{array}$ & 3.04 & 0.89 & Neutral & 4 \\
\hline
\end{tabular}


Table 7

Means and standard deviations of the statements of Dimension II: The behavioral support

\begin{tabular}{llcccc}
\hline Statements & Mean & SD & $\begin{array}{c}\text { Response } \\
\text { level }\end{array}$ & Order \\
\hline $\begin{array}{l}\text { 11. Remove any kind of } \\
\text { distractions to maintain my } \\
\text { focus and attention to } \\
\text { teacher. }\end{array}$ & 2.80 & 0.65 & Neutral & 8 \\
$\begin{array}{l}\text { 12. Allow classroom adjustment } \\
\text { and modifications. }\end{array}$ & 3.20 & 1.04 & Neutral & 2 \\
Total & 2.84 & 1.03 & Neutral & \\
\hline
\end{tabular}

SD = Standard Deviation

Areas in Social Support

As displayed in Table No. (8), responses demonstrated students' neutral attitude towards the availability of any kind of social support. More specifically, whereas students showed maximum level of agreement on receiving training on social cues, and learning problem-solving skills, they showed minimum level of agreement towards fostering respect, diversity, and acceptance through their familiarity with different cultures, and towards the availability of counseling services to discuss personal matters.

Table 8

Means and standard deviations of the statements of Dimension III: The social support.

\begin{tabular}{lrcccc}
\hline Statement & Mean & SD & $\begin{array}{c}\text { Response } \\
\text { level }\end{array}$ & Order \\
\hline $\begin{array}{l}\text { 1. Provide me with training } \\
\text { on social cues } \begin{array}{c}\text { for } \\
\text { understanding } \\
\text { messages. }\end{array}\end{array}$ & 3.20 & 1.04 & Neutral & 1 \\
$\begin{array}{l}\text { 2. Teach me verbal } \\
\text { communication skills - I lack } \\
\text { the ability to speak words. }\end{array}$ & 3.08 & 0.86 & Neutral & 3 \\
$\begin{array}{l}\text { 3. Enhance peer motivation. } \\
\begin{array}{l}\text { 4. Teach me problem-solving } \\
\text { skills. }\end{array}\end{array}$ 3.08 & $\mathbf{3 . 2 0}$ & $\mathbf{0 . 8 6}$ & Neutral & 4 \\
$\begin{array}{l}\text { 5. Reinforce my socially } \\
\text { significant behavior. }\end{array}$ & 2.92 & 0.91 & Neutral & 2 \\
\hline
\end{tabular}




$$
\text { كلية التزبية بالقاهرة العدد: (187)، مجربة الجزء (الثالث)، يوليو لسنة 2020م }
$$

Table 8

Means and standard deviations of the statements of Dimension III:

\begin{tabular}{|c|c|c|c|c|}
\hline Statement & Mean & SD & $\begin{array}{c}\text { Response } \\
\text { level }\end{array}$ & Order \\
\hline $\begin{array}{lrr}\text { 6. Make me familiar with } \\
\text { different cultures to foster } \\
\text { respect, } \\
\text { acceptance. }\end{array}$ & 2.88 & $\mathbf{0 . 8 3}$ & Neutral & 8 \\
\hline $\begin{array}{l}\text { 7. Provide me with ample } \\
\text { opportunities to work in } \\
\text { teams. }\end{array}$ & 2.92 & 0.91 & Neutral & 6 \\
\hline $\begin{array}{l}\text { 8. Provide me with } \\
\text { counseling services to } \\
\text { about personal matters. }\end{array}$ & 2.88 & 1.13 & Neutral & 9 \\
\hline 9. Promote my self-esteem. & 2.92 & 1.19 & Neutral & 7 \\
\hline Total & 3.01 & 0.97 & Neutral & \\
\hline
\end{tabular}
The social support.

SD $=$ Standard Deviation

\section{Areas in Physical Support}

As revealed in Table No. (9), responses revealed that neither occupational therapy, nor accessibility to the buildings and university facilities are ensured to students with LD. Nevertheless, and within the neutral range, responses demonstrated maximum level of agreement of the student respondents toward the existence of elevators for students with physical disabilities, and the availability of technical aids such as calculators, pencil grips, screens, hearing aids or enhanced speakers. While the responses demonstrated minimum level of agreement toward the existence of physical therapy, accommodation services for having food allergies such as providing alternatives, and the availability of medical files for emergency purposes as well as a reference for their medical history along with providing help to overcome any physical barriers that might present itself. 
Table 9

Means and standard deviations of the statements of Dimension IV: The physical support

\begin{tabular}{|c|c|c|c|c|}
\hline Statements & Mean & SD & $\begin{array}{l}\text { Response } \\
\text { level }\end{array}$ & Order \\
\hline 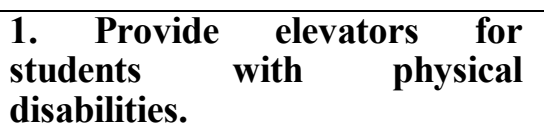 & 2.96 & 1.40 & Neutral & 1 \\
\hline 2. Provide physical therapy. & 2.60 & 1.41 & Neutral & 6 \\
\hline $\begin{array}{l}\text { 3. Provide occupational } \\
\text { therapy. }\end{array}$ & 2.20 & 1.00 & Disagree & 7 \\
\hline $\begin{array}{l}\text { 4. Provides accommodation for } \\
\text { having food allergies such as } \\
\text { alternatives. }\end{array}$ & 2.76 & 0.60 & Neutral & 4 \\
\hline $\begin{array}{l}\text { 5. Provide technical aids such } \\
\text { as calculators, pencil grips, } \\
\text { screens, hearing aids or } \\
\text { enhanced speakers. }\end{array}$ & 2.96 & 1.40 & Neutral & 2 \\
\hline $\begin{array}{l}\text { 6. Keep my medical file for } \\
\text { emergency purposes as well as } \\
\text { a reference for medical history. }\end{array}$ & 2.68 & 0.48 & Neutral & 5 \\
\hline $\begin{array}{l}\text { 7. Make sure buildings and } \\
\text { facilities are accessible. }\end{array}$ & 2.12 & 0.97 & Disagree & 8 \\
\hline $\begin{array}{l}\text { 8. Help me overcome any } \\
\text { physical barriers. }\end{array}$ & 2.84 & 0.75 & Neutral & 3 \\
\hline Total & 2.64 & 1.00 & Neutral & \\
\hline
\end{tabular}

\section{Areas in Moral Support}

As showed in Table No. (10), students' responses reported that their respective university and teachers do acknowledge their rights with dignity and respect, nevertheless responses revealed neutral attitudes of the students towards other moral related areas with varying levels of agreement. More specifically, student respondents showed higher level of agreement within the neutral range towards maintaining the integrity of academic standards, than towards maintaining confidentiality, disclosing students' disability in confidential place, and regarding professional care provided. 


$$
\begin{aligned}
& \text { كلية التربية بالزقاهرة العدد: (187)، الجزء (الثالث)، يوليو لسنة 2020م } \\
& \text { مجلة التربية }
\end{aligned}
$$

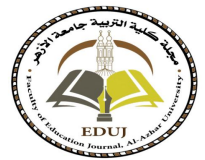

Table 10

Means and standard deviations of the statements of Dimension V: The

\begin{tabular}{|c|c|c|c|c|}
\hline Statements & Mean & SD & $\begin{array}{l}\text { Response } \\
\text { level }\end{array}$ & Order \\
\hline $\begin{array}{l}\text { 1. Allow me to disclose my disability in } \\
\text { an appropriate and confidential place. }\end{array}$ & 3.04 & 0.89 & Neutral & 4 \\
\hline $\begin{array}{l}\text { 2. Acknowledge my rights with dignity } \\
\text { and respect. }\end{array}$ & 3.44 & 1.04 & Agree & 1 \\
\hline $\begin{array}{l}\text { 3. Maintain the integrity of academic } \\
\text { standards. }\end{array}$ & 3.32 & 0.99 & Neutral & 2 \\
\hline $\begin{array}{l}\text { 4. Maintain my confidentiality at all } \\
\text { times. }\end{array}$ & 3.08 & 0.86 & Neutral & 3 \\
\hline 5. Provide me with professional care. & 3.00 & 0.82 & Neutral & 5 \\
\hline Total & 3.18 & 0.92 & Neutral & \\
\hline
\end{tabular}
moral support

SD $=$ Standard Deviation

Q2. What are the challenges that students face in their learning in HEIs in KSA?

To answer the second research question, descriptive statistics was used including mean and standard deviation for the answers of the statements of the sixth dimension: The main challenges.

\section{Challenges Faced By Students}

Table No. (11) presents findings that are related to the challenges that are faced by students with LD. In relevance to this dimension, students' responses revealed that most students with $L D$ are challenged with feedback on their work, and on ways to improve it, while responses demonstrated that they are not challenged with the language used. At the same time, student responses revealed neutral attitudes towards other challenges with varying extents. As the table below shows, more students with $L D$ are challenged with the way material is demonstrated to them, leading some to have difficulties in following instructions. Other problems that students with LD face is the settings in which they take exams in, followed by the way the material is presented. The time allowed for exams is also a hindrance for some students with $L D$, along with the way they present their learned information. Comes next, is the utilization of teaching methods, that includes the way cognitive 
training is provided. Finally, the way instructions are provided to them before the time allocated to complete courses does also pose an issue for students with $L D$.

Table 11

Means and standard deviations of the statements of Dimension VI: The main challenges

\begin{tabular}{|c|c|c|c|c|}
\hline Statements & Mean & SD & Response level & Order \\
\hline $\begin{array}{l}\text { 1. In the way the material } \\
\text { is presented }\end{array}$ & 3.12 & 1.42 & Neutral & 4 \\
\hline $\begin{array}{l}\text { 2. In the utilized teaching } \\
\text { methods }\end{array}$ & 2.88 & 1.13 & Neutral & 7 \\
\hline $\begin{array}{l}\text { 3. In the time allowed for } \\
\text { exams }\end{array}$ & 3.12 & 1.42 & Neutral & 5 \\
\hline $\begin{array}{l}\text { 4. In the time allowed to } \\
\text { complete courses }\end{array}$ & 2.72 & 0.94 & Neutral & 10 \\
\hline $\begin{array}{l}\text { 5. In the language used to } \\
\text { deal with me }\end{array}$ & 2.24 & 0.60 & Disagree & 11 \\
\hline $\begin{array}{l}\text { 6. In the way I present the } \\
\text { learned information }\end{array}$ & 3.00 & 0.82 & Neutral & 6 \\
\hline $\begin{array}{l}\text { 7. In the way material is } \\
\text { demonstrated for me to } \\
\text { know exactly what to do. }\end{array}$ & 3.24 & 1.30 & Neutral & 2 \\
\hline $\begin{array}{l}\text { 8. In the way feedback is } \\
\text { provided on my work and } \\
\text { how to improve it }\end{array}$ & 3.60 & 1.26 & Agree & 1 \\
\hline $\begin{array}{l}\text { 9. In the place I take } \\
\text { exams in }\end{array}$ & 3.20 & 1.00 & Neutral & 3 \\
\hline $\begin{array}{l}10 . \quad \text { In the way } \\
\text { instructions are provided } \\
\text { to me }\end{array}$ & 2.76 & 1.01 & Neutral & 9 \\
\hline $\begin{array}{l}\text { 11. In the way cognitive } \\
\text { training is provided to me }\end{array}$ & 2.88 & 1.13 & Neutral & 8 \\
\hline Total & 2.98 & 1.09 & Neutral & \\
\hline
\end{tabular}

SD $=$ Standard Deviation 
Q3. What are the challenges that teachers in HEIs in KSA face and hinder or limit providing support to students with learning disabilities?

To answer the third research question, descriptive statistics was used including mean and standard deviation for the answers of the statements of teachers' questionnaire.

\section{Teachers' Perspectives}

\section{Challenges Faced By Teachers}

Table No. (12) presents findings related to the challenges that teachers in HEIs face in supporting students with LD. Accordingly, results revealed, that the challenges that most teachers face, include but are not limited to, are; the unavailability of professional development programs for accommodating students with LD, not having proper communication with teachers to describe available cases and ways to deal with them, not having enough funds to allocate resources, not having reliable diagnostic reports for students suspected of having $L D$, not receiving awareness about types of support to provide to students with LD, an unavailability of an academic support center, and not having counseling services available for students with $L D$.

Table 12

Means and standard deviations of the statements of the challenges to support students with $L D$

\begin{tabular}{|c|c|c|c|c|}
\hline Statements & Mean & SD & esponse level & Order \\
\hline $\begin{array}{l}\text { 1. We do not have enough } \\
\text { funds to get resources. }\end{array}$ & 3.83 & 1.36 & Agree & 7 \\
\hline $\begin{array}{l}\text { 2. We do not have reliable } \\
\text { diagnostic reports for students } \\
\text { suspected of having LD. }\end{array}$ & 3.98 & 1.15 & Agree & 5 \\
\hline $\begin{array}{l}\text { 3. We do not receive } \\
\text { awareness about types of } \\
\text { support to provide to students } \\
\text { with LD. }\end{array}$ & 4.01 & 1.15 & Agree & 4 \\
\hline $\begin{array}{l}\text { 4. We do not have proper } \\
\text { communication with teachers } \\
\text { to describe available cases and }\end{array}$ & 4.30 & 0.85 & trongly agree & 2 \\
\hline
\end{tabular}




\title{
Table 12
}

Means and standard deviations of the statements of the challenges to support students with LD

\begin{tabular}{ll}
\hline Statements & Mean SD Response level Order \\
\hline ways to deal with them. &
\end{tabular}

5. We do not have academic support center.

4.11 1.16 Agree 3

6. We do not have counseling services available for students with LD.

3.94 1.02 Agree 6

7. We do not have professional development programs for accommodating students with LD.

\author{
4.39 0.71 Strongly agree \\ 1
}

\begin{tabular}{llll} 
Total & 4.08 & 1.06 & Agree \\
\hline SD $=$ Standard Deviation & &
\end{tabular}

\section{Discussion:}

This study is aimed at identifying the kind of support that HEIs in KSA provide to students with $L D$, along with describing the challenges that these students face in their learning from the standpoint of students with LD themselves. This goes with identifying the challenges that teachers in HEIs face that prevent them from providing the needed support. The varieties of support that were researched included academic support, behavioral support, social support, physical support, and moral support. That's in addition to, the relevant challenges that students with LD face in HEIs. These aspects are discussed in relation to the findings of this study, implications, limitations, and the need for additional research.

Like several previous studies that described the various kinds of support that students with LD need in HEIs to enhance their learning experience and maximize their achievements (Collinson \& Penketh, 2010; Gerber et al., 1990; Ingesson, 2007), the results of this study provides empirical evidence to the continuing deficit, or lack of certain kinds of support that students with $L D$ continue to require in their higher education in the city of 


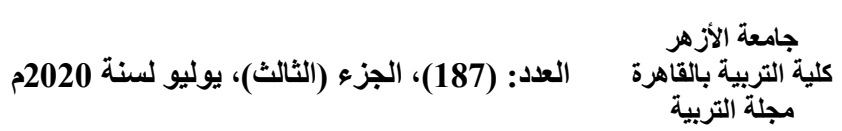

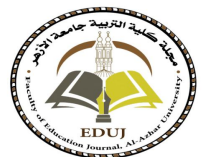

Jeddah in KSA. Students in this study reported the deficit in academic support, specifically in relation to cognitive training, the kind of support that is highly essential, especially in such a transitional period from secondary to higher education (Hadley \& Satterfield, 2013). In addition, they indicated the lack of training on study skills which is considered to be highly significant in helping students with $L D$ cope with the challenges in higher education, to enhance their learning and maximize their achievement (Fuller et al., 2004). Further to that, student participants reported the deficiency in the utilization of visually displayed materials by their teachers which help them better understand the taught concepts and related material, thus constitute crucial kind of support to enhance learning during their post-secondary education (Crawford, 2012). As far as special facilities, especially in terms of when physical support is concerned, student participants indicated the need of such type of support in order to help them face relevant challenges and overcome related obstacles (Alquraini, 2011).

From another perspective, teachers reported the very limited financial support provided by the HEIs as well as the government, means that more financial support is needed to help teachers secure the required materials and resources to better meet the needs of students with LD in HEIs, in extension to their support to students with LD at schools (Alquraini, 2011).

Although HEIs do admit students with LD to the various majors or programs to pursue their learning in undergraduate and post-graduate studies, yet these institutions should consider providing these students with the needed support at the academic, social, behavioral, and moral levels, to enhance their learning. This task should not only be a concern of the HEIs, but it should be a concern of the policy makers at the governmental level who are invited to set forth policies and practices that mandate HEIs to identify the students with $L D$ and to provide them with the appropriate services in compliance with the policies included in The Law of Disability in Saudi Arabia, 2000.

\section{Implications:}

This study is intended to contribute toward informing the policy makers about the needed kind of support and the special services that students with $L D$ in HEIs are in need of. It also intends to inform the challenges that students with $L D$ face in their learning via their own perspective. Furthermore, this 
research study addresses the underlying challenges that HEIs in KSA face, this specifically includes the hindrance of the provision of the necessary support given to students with $L D$ along with the teacher's assistance and opinion. Accordingly, this piece of research was intended to benefit the teachers, students with $L D$, administrators in HEIs, and even the policy makers in the Ministry of Education in the Kingdom, since it is designed to provide the different categories of support needed for these students to pursue their post-secondary education.

The findings of this study have important implications for both practical and future research. With respect to practice, institutions of higher education are responsible for providing the necessary services and support to students with $L D$ at all levels: academic, behavioral, social, physical and more. Furthermore, universities should provide teachers with the needed support to help them overcome identified challenges, especially in regard to providing professional development programs to educate them about $L D$ and related matters.

\section{Limitations:}

The findings of this study need to be viewed in light of several limitations. First, although the teachers' sample size is small, nevertheless, this study still gives insight towards the challenges that teachers in HEIs are facing and hampering the support needed to students with LD. Therefore, additional studies are necessary to secure a bigger sample to be able to generalize the results. Second, the students' sample is also small for a quantitative study; but the researcher was not able to obtain the total number of students with LD in both universities, which could be referred to the fact that these universities may not have the exact number of students with $L D$ for reasons including, the lack of proper diagnosis, ignorance of the students themselves about their own learning disability, or hiding a student learning disability form the administration. Moreover, obtaining responses from students with $L D$ is highly challenging due to several reasons, most important of which, is the fact that not all students with LD are properly diagnosed, and students who are diagnosed with LD tend not to respond due to the sensitivity of the topic in spite of the anonymity of the questionnaire. For this reason, the researcher had to refrain from conducting in depth interviews with students with LD who refused to participate. 


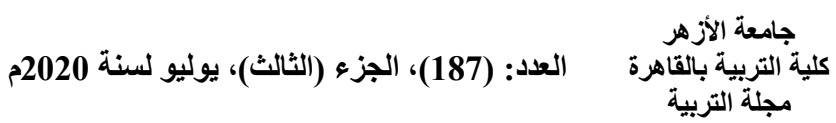

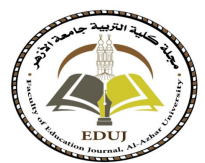

References:

Alharbi, A. \& Madhesh, A. (2018). Inclusive education and policy in Saudi Arabia. International Journal of Education Research and Reviews,6(1), 946-956.

Alamri, M. (2011). Higher education in Saudi Arabia. Journal of Higher Education Theory and Practice,11(4).

Aldabas, R.A. (2015). Special education in Saudi Arabia: History and areas for reform. Creative Education, 6, 1158-1167.

Alkhashrami, S. (2011). Evaluation of the related support services at King Saud University for students with special needs. King Saud University Journal, Journal of Educational Sciences and Islamic Studies 1(23), 99-134.

Al-Mousa, N. A., Al-Sartawi, Z. A., Al-Adbuljbbar, A. M., Al-Btal, Z, M., \& Al-Husain, A. S. (2006). The national study to evaluate the experiment of the Kingdom of Saudi Arabia in mainstreaming children with special educational needs in public education schools. Retrieved from Directorate General of Special Education website: http://www.se.gov.sa/Inclusion.aspx

Alothman, A. (2014). Inclusive education for deaf students in Saudi Arabia: Perceptions of schools principals, teachers and parents. (Doctoral dissertation), University of Lincoln.

Alquraini, T. (2011). Special education in saudi arabia: Challenges, perspectives, future possibilities. International Journal Of Special Education, Vol 26, No: 2, 2011.

Alquraini, T. A. (2011). Teachers' Perspectives of Inclusion of the Students with Severe Disabilities in Elementary Schools in Saudi Arabia. Unpublished Doctoral Dissertation, Athens: Ohio University.

Al-Rawaf, H. \& Simmons, C. (1991). The education of women in Saudi Arabia. Comparative Education, 77, 187-295.

American Psychiatric Association. (2013a). Diagnostic and Statistical Manual of Mental Disorders, 5th ed. Washington, D.C.: American Psychological Association.

American Psychiatric Association. (2013b). Specific Learning Disorder. Retrieved from http://www.dsm5.org/ Documents/Specific\%20Learning\%20Disorder\%20 Fact\%20Sheet.pdf 
Bin Battal, Z.M. (2016). Special education in Saudi Arabia. International Journal of Technology and Inclusive Education (IJTIE), 5(2), 880-886.

Bishnoi, N. (2017). Learning challenges and remedial strategies: A conceptual paper. Indian Journal of Health and Wellbeing, $8(7), 754-756$

Collinson, C., \& Penketh, C. (2010). Sit in the corner and don't eat the crayons: Postgraduates with dyslexia and the dominant "lexic" discourse. Disability \& Society, 25(1), 7-19.

Crawford, C. (2012). Youth with disabilities in transition from school to work or post-secondary education and training: $A$ review of the literature in the united states and united kingdom. Institute for Research and Development on Inclusion and Society (IRIS) Kinsmen Building, York University

Cronbach, L. J. (1951). Coefficient alpha and the internal structure of tests. Psychometrika, 16(3), 297-334.

Fletcher, J.M., Lyon, G.R., Fuchs, L., \& Barnes, M. (2007). Learning disabilities: From identification to intervention. New York, NY: Guilford Press.

Fuller, M., Healey, M., Bradley, A., \& Hall, T. (2004). Barriers to learning: A systematic study of the experience of disabled students in one university. Studies in Higher Education, 29(3), 303-318.

Gerber, P. J., Schnieders, C. A., Paradise, L. V., Reiff, H. B., Ginsberg, R. J., \& Popp, P. A. (1990). Persisting problems of adults with LD: Self-reported comparisons from their school-age and adult years. Journal of LD, 23(9), 570-573.

Gibson, S., \& Kendall, L. (2010). Stories from school: Dyslexia and learners' voices on factors impacting on achievement. Support for Learning, 25(4), 187-193.

Goode, J. (2006). Managing disability: Early experiences of university students with disabilities. Disability \& Society, 22(1), 35-48.

Hadley,W.M. \& Satterfield, J.W.(2013). Are University Students with Learning Disabilities Getting the Help They Need? Journal of The First-Year Experience \& Students in Transition, (25)1,113-123

Hair, J., Black, W., Babin, B., Anderson, R., \& Tatham, R. (2006). Multivariate data analysis (6th ed.). Upper Saddle River, N.J.: Pearson Prentice Hall. 
Heiman, T. \& Precel, K. (2003). Students with LD in higher education: Academic strategies profile. Journal of Learning Disailities, 36(3), 248-258.

Herring, N. L. (2012). LD, Postsecondary Education, teacher attitudes, administrator attitudes, skill development, readiness, allied health personnel, higher education, postsecondary education, higher education. ProQuest LLC, Ed.D. Dissertation, Ball State University. 505 pp.

Hutcheon, E. J., \& Wolbring, G. (2012). Voices of "disabled" post secondary students: Examining higher education "disability" policy using an ableism lens. Journal of Diversity in Higher Education, 5(1), 39-49.

Ingesson, S. G. (2007). Growing up with dyslexia: Interviews with teenagers and young adults. School Psychology International, 28(5), 574-591.

Jones M. \& Rattray J. (2010). Questionnaire design. In The Research Process in Nursing, 6th ed. (Gerrish K. \& Lacey A., ed.), Wiley-Blackwell, Oxford

Lahane, S., Shah, H., Nagarale, V., \& Kamath, R. (2013). Comparison of self-esteem and maternal attitude between children with learning disability and unaffected siblings. Indian Journal of Pediatrics, 80(9), 745-749. doi: 10.1007/s12098-012-0915-5.

Lewis, K. E. (2011). Toward a reconceptualization of mathematical learning disabilities: A focus on difference rather than deficit. (Doctoral dissertation). University of California, Berkeley.

Mortimorea, T. \& Crozier, R. (2006). Dyslexia and difficulties with study skills in higher education. Studies in Higher Education, (31), 235-251.

Polit, D.F. and Beck, C.T. (2010) Essentials of nursing research: Appraising evidence for nursing practice. $7^{\text {th }}$ Edition, Wolters Kluwer Health/Lippincott Williams \& Wilkins, Philadelphia.

Robson, C. (2007). How to do a research project: A guide for undergraduate students, Qualitative Research in Psychology, (4)4, 349, DOI: 10.1080/14780880701533319.

Vargo, F. E. (2015). Neurodevelopment disorders: A definitive guide for educators. New York, NY: Norton. 